DOI: $10.22616 /$ REEP.2019.027

\title{
Impact of Local Action Groups on Improving Professional Competences of Rural Residents
}

\author{
Julia Wojciechowska-Solis Dr. \\ University of Life Sciences in Lublin, Department of Agritourism and Rural Development, Poland \\ julia.wojciechowska@up.lublin.pl
}

\begin{abstract}
Trainings, which are perceived as the process of acquiring new knowledge, skills and abilities or enhancing and upgrading those already possessed are undoubtedly the basic tools for human resources development. It is recognized that trainings should lead to improving skills and increasing qualifications and competences. Access to trainings is limited in rural areas due to geographic coverage and financial reasons (charges). The solution may be trainings and courses organized by LAGs in cooperation with other entities in the areas where they operate. The aim of the article was to assess the activities of the Krasnik Land LAG in terms of effectiveness of organized trainings, increasing the competences of local entrepreneurs in areas where LAG operates. The research also sought to determine the impact of trainings in customer satisfaction management on the level of customer satisfaction of rural entrepreneurs taking part in the training. The Servqual method and statistical program, Statistica 13PL, were used to analyse the results. The most important results include two positive gaps in the area of responsiveness and empathy for the evaluation of trainings organized by the LAG. LAG respondents also highly rated the selection of the proper training companies. Building social capital in the rural areas is the condition for stimulating the involvement of the local community in the development of the region and better use of its resources. It should be emphasized that training organized by the LAG is very popular among residents running businesses in the analysed 9 municipalities. Respondents pointed out free admission to trainings, topics important for the development of their businesses related to the development of their region.
\end{abstract}

Keywords: rural development, Local Action Groups, professional competences, training.

\section{Introduction}

\section{The importance of LAGs for improving the quality of life}

Activation of rural areas is a significant challenge for Polish villages, where unemployment is the biggest problem, which is particularly difficult to eliminate in agricultural areas. The majority of residents living up to now from agricultural production will have to retrain and acquire a new source of income in the near future due to the changing trends on the Polish and global agricultural market (Koulouris, Sotiriou, 2010).

Efforts of both central and local authorities, which are aimed at the main objective, i.e., preserving the cultural heritage of individual countries, have led to the implementation of the idea of rural development by Local Action Groups (LAGs). The LAG's main activities are directed to the development and promotion of individual regions and mobilization of their potential. They are intended to promote the improvement of competitiveness and contribute to the activation and cooperation of local communities (Pelucha, 2006).

The European Union structural policy addressed to rural areas is financed from two independent sources: cohesion policy and Common Agricultural Policy (Kuhmonen, 2018), which can be characterized as: the need to co-finance expenditure by Member States, introduction of programs at the national level, plurality of beneficiary groups and difficulties with an unambiguous assessment of program effects.

LAGs have been a new entity in the Polish social reality since 2004, because they grouped people interested in making changes at their place of residence. The principle of LAGs is to involve entities from both the public and private sector, while the public sector cannot have more than $50 \%$ of votes in the authorities making the most important decisions (Szymanska, 2017).

Since 1991, the LEADER (Wojciechowska-Solis, Soroka, 2017) focus has been introduced in the European Union, which has become a method of stimulating the activity of local communities and their involvement in the search and utilization of potential in rural areas. In its assumptions, LEADER is constructed on the grassroots partner initiative and on the innovative approach to rural development. It is also the implementation of projects resulting from it that combine resources, knowledge and skills of local community representatives (The leader approach..., 2006). 
The Local Action Group is primarily people who want to create better living conditions for all residents through the utilization of local resources. The partners undertake joint, practical activities, sharing resources, responsibility and benefits. Local Action Groups, using all the possibilities offered by Poland's membership in the European Union, can become a powerful local organization that creates the development of the entire region (Doitchinova, Stoyanova, 2014). Cooperation with partners in other regions of Poland and the European Union is a very important element of its operation.

\section{The importance of professional competence}

Competence-based management standardizes and integrates all activities that accomplish corporate goals regardless of its size. It provides determination of basic requirements for employees at their job positions, directs the development of human capital, contributing to the improvement of competitiveness. Competence-based management is also shaping the behaviour of employees. It is the best method for determining job requirements, building strategic programs in the field of human resources, developing qualified, committed employees, improving the efficiency of the company's operations. Competences have an impact on the results of the activity, they contribute to achieving a high level of individual inputs to the development of an organization (Kolibacova, 2014).

According to R.E. Boyatzis (2008), competence is a human potential that leads to such behaviour, which contributes to fulfilment of the requirements at a given workplace within the parameters of the organization's environment, which produces the desired results. S. Iriste and I. Katane (2015) described competence as the ability to fulfil tasks and roles according to the expected standards. This definition perceives competence as the acquisition of standards defined by society. The authors perceive competence as the ability acquired in the educational process and based on knowledge, experience and attitude. Such ability manifests itself as a skill - readiness to act.

The labour market today requires employees and self-employed to constantly improve their professional qualifications and flexibility. Unfortunately, many employers do not invest in the development of their staff, at the same time requiring more and more skills from them, thus transferring high costs of increasing competences to employees.

The most popular form of improving employee qualifications are trainings that include learning processes implemented in the organization, aimed at raising qualifications, supplementing them with new elements of knowledge, skills, personal qualities or behaviours. The most popular forms of modern employee improvement methods include coaching, mentoring and tutoring. Employee competences are becoming more and more important. Currently, the most desirable competencies are: team work, leadership, communication skills, customer focus, flexibility and stimulating the development of others (Riggio et al., 2003).

The use of European funds by employers and non-profit organizations has a large impact on the strategies of training companies. Local Action Groups are an appropriate intermediary link between a training company and the final beneficiary, i.e. a person applying for increasing their professional competences.

The aim of the article was to assess the activities of the Krasnik Land LAG in terms of effectiveness of organized trainings, increasing the competences of inhabitants-entrepreneurs in areas where LAG operates. The research also sought to determine the impact of trainings in customer satisfaction management on the level of customer satisfaction of rural entrepreneurs taking part in the training. An attempt was made to estimate the importance of individual dimensions in the evaluation of the studied service by respondents through the use of the Servqual method (Sawicki, Wojciechowska-Solis, 2010). The area on which the Krasnik Land LAG is operating is considered one of the poorest regions of the European Union, which is why residents participate in organized trainings with great interest, trying to diversify their income and become independent from agriculture.

\section{Methodology}

The development of human capital is very important in rural areas. The same requirements are imposed on the public living in areas outside the urban agglomerations as well as on urban residents. For some companies, barriers of sending an employee to trainings increasing their professional competences may stem from logistic and financial factors (Barefield, 2009).

In Poland, building grassroots elements of public-private partnership as well as social partnership and their functioning is a positive experience for communities living in rural areas (EU European 
Commission, 2013). On the one hand, these groups are the authors of the local area development strategy where they conduct their activities, and on the other hand, they act as beneficiaries of assistance, while at the same time they are institutionally responsible for the implementation of development strategies and spending EU funds allocated for this purpose. The initiatives undertaken by public, economic and social entities as part of the three-sector partnerships contribute to the improvement of the quality of life of rural areas inhabitants.

The goal of local action groups is to improve the quality of life of residents in their region and increase social and economic activity in the LAG area (Zajda, Kretek-Kaminska, 2013). The objectives were recorded in Local Development Strategies.

Implementing Axis IV - LEADER, as part of RDP Local Action Groups, conduct three types of activities, on the basis of agreements with the Voivodeship Marshal's Office as the Implementing Institution:

- implementing Local Development Strategies;

- implementing cooperation projects;

- functioning of the Local Action Group, acquiring skills and activation.

By implementing local LAG development strategies as part of announced tenders - calls for proposals, they select projects for financing, submitted by local institutional or private entities under four financial categories: renewal and development of rural areas, creation and development of micro-enterprises, diversification into non-agricultural activities, and so-called small projects related to the development of tourism, culture, education, sport, tradition and regional heritage.

This study included persons running businesses (micro-enterprises) in the field of tourism development, namely entities providing tourist services, agritourism, rental of equipment for tourism in rural areas and food services in the region of the Krasnik Land LAG. The Krasnik Land LAG operates in 9 municipalities, most of which comprises rural areas.

The study was conducted in the period of June-August 2018. The research sample included 120 microenterprises (persons operating a business). Enterprises were selected based on the availability from 9 municipalities covered by the LAG and a declaration of using the training offer proposed by the Krasnik Land LAG. When selecting businesses to the experimental sample, the confidence level was set at 0.95 , the estimated fraction size was determined at 0.50 and the maximum error was set at 0.05 . The study used the method of a diagnostic survey, with an original research tool in the form of a questionnaire. The Servqual method was used for further analysis. The questionnaire consisted of two parts and contained 22 questions each. The five-point Likert scale was used to measure the attitudes.

The Servqual method is aimed at determining the differences between the quality of the perceived service and the quality provided by a specific company, which allows estimating the degree of customer satisfaction with the services provided (Wojciechowska-Solis, Mazurek-Kusiak, Soroka, 2016). Evaluation is carried out from the point of view of the five dimensions of service quality: tangibles (I), reliability (II), liability of suppliers (III), confidence (IV) and affordability (V). Considering individual dimensions, tables were designed in the third part of the survey, which was intended to weigh the tested dimensions (Zeithaml, Berry, Parasuraman, 1988; Sawicki, Wojciechowska-Solis, 2010). Based on the unweighted Servqual results, one can conclude which of the elements of the service provided should be further analysed in order to achieve its most optimal level of quality. The calculated unweighted Servqual result can have a positive, negative or zero value. A positive result means obtaining better quality/satisfaction than customer's expectations; a negative result indicates a failure to meet expectations. The most optimal situation is when the result is zero, which means that the service exactly meets customer expectations. The weighted Servqual index is acquired with the third part of the survey, in which respondents weigh particular areas and nonweighted Servqual indices (the sum of the weights should amount to 100).

The Statistica 13 PL (StatSoft, 2019) software was used in statistical analyses. An analysis of descriptive statistics and Student's t test were applied. Prior to the analysis, multivariate normality was examined, testing each variable for normal distribution. Slight deviations were omitted, due to the number of variables in each group. Means were considered statistically significant differences; which probability was less than $\mathrm{p}<0.05$. 


\section{Results and Discussion}

Entrepreneurs entering the trainings expect that the acquired knowledge will help them to obtain information on managing their clients' satisfaction, as well as find new directions for improving the quality of products or services offered.

The respondents were asked to indicate the level of their expectations regarding the trainings they participated in and the opportunities that would help them to achieve. The actual state was recorded in the second part of the study - what was achieved after the trainings offered by the LAG and the level of meeting expectations. The results show differences between the expectations of the training beneficiaries and the state of the service provided to improve their qualifications.

The "difference" shown in Table 1 between the obtained Ex post and Ex ante variables among the training participants illustrates the quality of the provided training service. Expectations indicated before the training were higher in three areas: tangibility, reliability, confidence. Expectations of people participating in the trainings were met in the areas of responsiveness and empathy. Currently, in the age of the Internet and general access to information and focusing on quality, and not on cheapness of the tender, companies that win them provide services at a very high level. Gaps in the "in plus" areas prove that people who were employed to provide training services seriously approached the problems faced by the participants and tried to help them in solving them. The response to the questions was very highly rated.

Table 1

Differences in expectations (Ex ante) and perceptions (Ex post) of the quality of services provided by training beneficiaries and differences in data values presented as absolute values

\begin{tabular}{|l|c|c|c|}
\hline \multicolumn{1}{|c|}{ Dimension/area } & Ex ante & Ex post & Difference \\
\hline Tangibility (I) & 4.187 & 4.063 & -0.124 \\
\hline Reliability (II) & 4.488 & 4.464 & -0.024 \\
\hline Responsiveness (III) & 4.347 & 4.401 & 0.054 \\
\hline Confidence (IV) & 4.558 & 4.508 & -0.050 \\
\hline Empathy (V) & 4.304 & 4.391 & 0.087 \\
\hline Average & 4.377 & 4.365 & -0.011 \\
\hline
\end{tabular}

The negative gap shows the areas that should be improved during the next trainings. Attention should be paid to the size of the room, the availability of information about further trainings, information on how to get to the place of training. The lower assessment of the area of trust speaks about the person conducting the training, its behaviour during the training, and the ability to provide information. Summing up the results presented in the table below, the participants appreciated the value of trainings organized by the LAG, as well as the selection of companies providing the service, they indicated areas where corrective actions should be taken.

Table 2

\section{Unweighted and weighted Servqual indices for the surveyed enterprises benefiting from the} training offer

\begin{tabular}{|c|c|c|c|}
\hline Dimension/area & $\begin{array}{c}\text { Unweighted } \\
\text { Servqual }\end{array}$ & $\begin{array}{c}\text { Weight } \\
\text { given }\end{array}$ & $\begin{array}{c}\text { Weighted } \\
\text { Servqual }\end{array}$ \\
\hline Tangibility (I) & -0.124 & 26.54 & -3.291 \\
\hline Reliability (II) & -0.024 & 22.13 & -0.535 \\
\hline Responsiveness (III) & 0.054 & 18.94 & 1.023 \\
\hline Confidence (IV) & -0.050 & 17.14 & -0.857 \\
\hline Empathy (V) & 0.087 & 15.15 & 1.318 \\
\hline Average & -0.011 & Sum: 100 & -0.468 \\
\hline
\end{tabular}

The Servqual analysis also allowed to estimate the importance of individual dimensions in the assessment of the analysed service. The weights given showed (Table 2) that tangibility and reliability dimensions were very important for the training participant in the service provided. Three distinct gaps 
could be observed after taking into account the weights given in the assessment of the quality of training services: two positive and one negative. The weighted Servqual indicator helps select the most important gaps among the existing ones, which are the most important during customer decision making. The tangibility, responsiveness and empathy gaps were significant in the analysed case of the evaluation of training service quality. While the "empathy" and "responsiveness" gaps were positive and did not need corrective action, the negative result of the "tangibility" gap requires the attention of the LAG when organizing further trainings.

The values of the five-dimension Servqual index were compared among enterprises participating in the training organized by the LAG. In all instances, significant differences were demonstrated in the evaluated dimensions at $p<0.050$ (Table 3 ). Building social capital in the rural areas is the condition for stimulating the involvement of the local community in the development of the region and better use of its resources. It should be noted that trainings organized by the LAG are very popular among microenterprises in the analysed 9 municipalities. Respondents pointed out free admission to trainings, topics important for the development of their businesses related to the development of their region.

T test for weighted Servqual of surveyed enterprises in specific areas

Table 3

\begin{tabular}{|c|c|c|}
\hline Dimension/area & T test & P value \\
\hline Tangibility (I) & -2.081 & $0.035^{*}$ \\
\hline Reliability (II) & -2.588 & $0.008^{*}$ \\
\hline Responsiveness (III) & -9.075 & $0.001^{*}$ \\
\hline Confidence (IV) & -3.711 & $0.001^{*}$ \\
\hline Empathy (V) & -6.397 & $0.001^{*}$ \\
\hline
\end{tabular}

where $*$ significant difference at $\mathrm{p}<0.050$

Y.K. Lee (Lee et al., 2011), A. Patiar and L. Mia (2009) found that improving qualifications positively influenced behaviour and motivated mutual help. In addition, the study of S.B. MacKenzie (MacKenzie et al., 2001) demonstrated that trainings had a positive impact on improving work performance and development of organizational culture of the enterprise, and these factors had a direct impact on the quality of service. Funds allocated for LAG trainings are obtained from EU Funds, therefore it selects training companies that meet the requirements - they provide their services at a very high level, confirmed by appropriate certificates. It is worth noting that currently, an interesting LAG training project is aimed at the residents of rural areas, concerning acquiring skills in vanishing craft trades, such as cooper, weaver, wickerworker, thatcher, wattler, liquers (nalewka) producers, herbalist, saddler, stonemason, which would later contribute to opening small craft workshops with very rare specializations. According to G. Wiesinger (2007), activation, promotion or training activities conducted by the Local Action Groups are of particular importance for rural development due to the generally low level of activity and involvement of rural communities in Polish villages in local structures and unwillingness to cooperation.

\section{Conclusions}

The situation in Polish rural areas is difficult, according to the rankings, the Eastern Poland region (the area of the Krasnik Land LAG operation) ranks at one of the last places in the European Union, according to the per capita income criterion. The LEADER approach tries to eliminate differences in the development of rural areas between regions of the European Union through the implemented LAG projects. The tasks are ambitious, their implementation depends on many factors. One of them is raising qualifications and gaining new skills by the inhabitants of rural areas, and thus - starting a business. The LAG's activity in the area of organizing training courses and study visits is very important for the development of rural areas, as well as the diversification of the income of its inhabitants.

The research carried out indicated that:

- market requirements put companies operating in rural areas ahead of the challenge related to increasing the professional competence of their employees; companies see their chances in various training programs implemented by the LAG's; 
- the quality of services/products created in rural areas is of fundamental importance for the functioning of rural enterprises; it is the level of quality or customer satisfaction that determines the decision to select a service or product, and thus the existence of a given enterprise in rural areas; the use of LAG training services helps entrepreneurs to obtain the necessary knowledge for further development of their business;

- measuring the quality of services by the Servqual method helps in detecting and correcting any deficiencies in the provided training service, aimed at increasing competences or acquiring new skills; it allows to learn the expectations of potential customers and adjust the level of service to market requirements;

- the importance of trainings organized by LAGs is of great significance to their beneficiaries due to their subject matter, the selection of training companies, and often their free admission.

Local Action Groups represent the non-governmental sector, which by definition is created by people and for people. LAGs are distinguished from other organizations by one hundred percent financing of their activities from external funds, i.e., as long as a given group exists and implements the goals set in the strategy, it is supported by EU funds. This comfortable situation means that the organization, without having to worry about its own survival, successfully implements activities for the community in which it operates.

\section{Bibliography}

1. Barefield A. (2009). Discussion: Human Capital and Rural Economic Development. Journal of Agricultural and Applied Economics. 41 (2), 431-433.

2. Boyatzis R.E. (2008). Competencies in the 21 st century. Journal of Management Development, 27 (1), 5-12.

3. Doitchinova J., Stoyanova Z. (2014). Activition of local communities for development of rural areas. Economics of Agriculture, 61(3), 661-675.

4. EU European Commission. (2013). Common Guidance of the European Commission's Directorates-General AGRI, EMPL, MARE and REGIO on Community-led Local Development in European Structural and Investment Funds. (Eds), Guidance for Local Actors on CommunityLed Local Development Retrieved from

https://ec.europa.eu/regional_policy/sources/docgener/informat/2014/guidance_clld_local_actors_en.pdf

5. Iriste S., Katane I. (2015). Prospective Hospitality Managers Competence as Integral Part of Competitiveness. In V. Dislere (Ed.), The Proceedings of the International Scientific Conference. Rural Environment. Education. Personality (REEP), 8, Jelgava: LLU, TF, 42-49. Retrieved from http://lufb.llu.lv/conference/REEP/2015/Latvia-Univ-Agricult-REEP-2015proceedings-42-49.pdf

6. Kolibacova G. (2014). The Relationship Between Competency and Performance. Acta Universitatis Agriculturae et Silviculturae Mendelianae Brunensis, 62 (6), 1315-1327. Retrieved from https://acta.mendelu.cz/media/pdf/actaun_2014062061315.pdf

7. Koulouris P., Sotiriou S. (2010). Supporting Rural Citizens' Access to Knowledge: One More Aspect of e-Democracy. In: A.B. Sideridis, C.Z. Patrikakis (Eds.), Next Generation Society. Technological and Legal Issues. e-Democracy 2009. Lecture Notes of the Institute for Computer Sciences, Social Informatics and Telecommunications Engineering, 26. Berlin, Heidelberg: Springer, 309-319.

8. Kuhmonen T. (2018). The Evolution of Problems Underlying the EU Agricultural Policy Regime. Journal of the European Society for Rural Sociology, 58(4), 846-866.

9. Lee Y.K., Kim Y., Son M.H., Lee D.J. (2011). Do emotions play a mediating role in the relationship between owner leadership styles and manager customer orientation, and performance in service environment? International Journal of Hospitality Management, 30, 942-952.

10. MacKenzie S.B., Podsakoff P.M., Rich G.A. (2001). Transformational and transactional leadership and salesperson performance. Journal of Academy of Marketing Science, 29, 115-134.

11. Patiar A., Mia L. (2009). Transformational leadership style, market competition and departmental performance: evidence from luxury hotels in Australia. International Journal of Hospitality Management, 28(2), 254-262.

12. Pelucha M. (2006). Rural development in the programming period 2007-2013 in the context of EU CAP reforms. Prague: IREAS. Institute for Structural Policy. 
13. Riggio R.E., Riggio H.R., Salinas Ch., Cole E.J. (2003). The role of social and communication skills in leader emergence and effectiveness. Group Dynamics Theory Research and Practice. 7(2), 83-103.

14. Sawicki B., Wojciechowska-Solis J. (2010). TQM a potencjal konkurencyjny biur turystycznych wojewodztwa lubelskiego i obwodu winnickiego (TQM and the competitive potential of the tourist offices of the Lubelskie voivodeship and the Vinnytsia region). Zeszyty Naukowe Ekonomiczne, Problemy Ustug, 53, 447-461. (in Polish)

15. StatSoft. (2019). Retrieved from https://www.statsoft.pl/statistica_13_3/

16. Szymanska M. (2017). Functions of Local Partnership in Rural Development. Studia Iuridica Lublinensia, 26(1), 331-345.

17. The leader approach: basic guide. (2006). Luxembourg: Office for Official Publications of the European Communities. Retrieved from https://ec.europa.eu/agriculture/sites/agriculture/files/publi/fact/leader/2006_en.pdf

18. Wiesinger G. (2007). The importance of social capital in rural development, networking and decision making in rural areas. Journal of Alpine Research, 95(4), 43- 56.

19. Wojciechowska-Solis J., Mazurek-Kusiak A., Soroka A. (2016). The influence of specialized training on the quality of hotel customers service. Acta Scientarum Polonorum, Oeconomia, 15(2), $173-185$.

20. Wojciechowska-Solis J., Soroka A. (2017). Funkcjonowanie LGD Ziemi Krasnickiej jako przyklad aktywizacji obszarow wiejskich w krajach Unii Europejskie (Operation of LAG Krasnik Area as an Example of Rural Areas Activation in EU Countries), Zeszyty Naukowe Szkoty Gtownej Gospodarstwa Wiejskiego w Warszawie Problemy Rolnictwa Swiatowego, 17(2) (XXXII), 298304. (in Polish)

21. Zajda K., Kretek-Kaminska A. (2013). Professionalisation and economisation of rural NGO's and the activity of their members. An example of local action groups from Wielkopolska. Journal of Agribusiness and Rural Development, 1(27), 249-260. Retrieved from http://dspace.uni.lodz.pl:8080/xmlui/bitstream/handle/11089/5794/Zajda\%2c\%20KretekProfesionalization-ENG.pdf? sequence $=1 \&$ isAllowed $=\mathrm{y}$

22. Zeithaml V.A., Berry L.L., Parasuraman A.A. (1988). Communication and Control processes in the delivery of service quality. Journal of Marketing. 52, 35-48. 